\title{
캄보디아 원조동향 보고
}

캄보디아 개발위원회는 9.12(화) Chhieng

Yanara 사무총장 주재하에 캄보디아 개발협력 포럼 출범에 대한 의견수렴 및 조정 등을 목적으 로 공여국회의를 개최하였는 바, 주요사항 아래 보고함.

\section{1. 회의개요}

- 일시 : 2006.9.12(화) 15:00 16:00

- 장소 : 캄보디아 개발위원회(Council for Development of Cambodia, CDC)

- 참석기관 : KOICA, UNDP, JICA, DANIDA, World Bank 등 캄보디아 외교부 등 주요 부처 차관 참석

\section{2. 회의배경}

- 캄보디아 정부는 2006.3.2. 원조공여국회의 (CG, Consultative Group) 에서 수차례의 원조공여국 회의(Consultative Group) 공동 의장직 경험을 바탕으로 원조공여기관과의 협의시 캄보디아 정부의 주도적인 역할에 대한 강한 의지를 표명한 바 있음

- 상기관련, 캄보디아 정부는 원조공여국 회 의(Consultative Group) 를 2007년부터 캄 보디아 개발협력포럼(CDCF, Cambodia Development and Cooperation Forum)으 로 전환키로 결정함

- 캄보디 아개발 위 원 회 (Council for Development of Cambodia)에 속한 캄보디 아 복 구 개 발 위 원 회 Cambodia Rehabilitation\& Development) 는 동 포 럼 출범을 위하여 실무검토를 실시하였으 
며, 캄보디아 정부는 동 실무검토(안)을 바탕 으로 현재 원조공여기관들로부터 의견을 수 렴중에 있음

- 의견수렴 내용 : 캄보디아 개발협력포럼 $(\mathrm{CDCF})$ 절차, $\mathrm{LDF}$ (Leading Donor Facilitator) 및 캄보디아 정부의 역할분 담, 기술실무위원회(TWG) 및 정부·공여 국간 협력위원회(GDCC)의 상관관계

- 금번 공여국회의도 캄보디아 정부의 원조공 여기관에 대한 의견수렴 노력의 일환으로 개최되었으며, 양자 및 다자 공여기관의 최 종의견 취합후 정부 내부절차를 거쳐 2006.10.5 정부·공여국간 협력위원회 (GDCC) 회의 시 포럼 출범 관련 최종안을 확정할 예정임

\section{3. 주요 쟁점사항}

- UNDP측에서는 동 포럼 관련 캄보디아 정 부의 단독적인 지표개발을 지양하고, 개발 파트너(Development Partners)와의 협의 및 합의하에 공동 모니터링 지표를 개발할 것을 건의함

- 캄보디아 정부 및 공여기관 대다수가 신흥 공여기관(emerging donors) 의 캄보디아 개발협력포럼에 대한 참여확대는 환영하였 으나, 시민사회(civil society)의 동 포럼 참 여에 대해서는 의견이 엇갈림

- $\mathrm{ADB}$ 등 일부 공여기관들은 시민사회의
캄보디아에 대한 원조기여도를 파악하기 어려운 점을 감안, 시민사회의 캄보디아 개발협력포럼 참여를 건의함.

- 그러나, Eiichiro Hayashi JICA 협력조정 자문관은 캄보디아에는 수많은 시민사회 가 있으며, 대부분의 시민사회가 지원공여 주체 (main sources)가 아닌 집행자 (executing agency)인 점을 언급하면서, 시민사회의 동 포름 참여에 부정적 견해를 표명함.

- UNDP 등 일부 원조공여기관은 캄보디아 정부의 원조공여 총액 대한 공식발표 이전 에 공여기관별 지원공약 발표를 건의함

\section{4. 캄보디아 개발협력포럼(CDCF) 주요내용}

- 2007년 캄보디아 개발협력포럼(CDCF)이 최초로 개최될 예정이며 캄보디아 정부가 의장직을 맡고, 캄보디아 복구개발위원회 $(\mathrm{CRDB})$ 는 캄보디아 정부의 조정기구로서 캄보디아 개발협력포럼 준비 및 조직관련 주요 역할을 수행할 예정임

- 세계은행은 캄보디아 개발협력포럼(CDCF) 의 Lead donor Facilitator (LDF)로서, 캄 보디아 개발협력포럼 $(\mathrm{CDCF})$ 의 사무국인 캄 보디아 복구개발위원회(CRDB)에 자문을 제공할 수 있음

- $\mathrm{LDF}$ 또는 타 원조공여기관은 캄보디아 개 발협력포럼(CDCF) 준비 및 조직을 위하여 
캄보디아 개발협력포럼 사무국에 재정적 지 원을 제공할 수 있음

- 캄보디아 정부는 $\mathrm{LDF}$ 를 통해 원조공여기관 과의 협의 및 합의하에 캄보디아 개발협력 포럼(CDCF)의 개최시기, 의제, 형식 등을 확정함

- 캄보디아 정부는 캄보디아 개발협력포럼 $(\mathrm{CDCF})$ 의 이해제고를 위하여 협력사업의 진행현황 및 문제점 등에 대한 보고서를 제 공하며, 아울러 원조공여기관도 동 사항에 대한 독립적인 분석 및 평가보고서(분야별/ 주제별 평가보고서 둥)를 제공할 수 있음.

- 한편, 캄보디아 복구개발위원회(CRDB)는 $\mathrm{LDF}$ 와의 협력하에 캄보디아 개발협력포럼
$(\mathrm{CDCF})$ 개최 전 지원공약서를 준비, 배포할 예정이며, 개발협력포럼 종료 시 원조공여 기관의 지원공약 총액을 집계하여 캄보디아 정부가 공식 발표하게됨

- 캄보디아 복구개발위원회는 $\mathrm{LDF}$ 와의 협력 하에 언론 보도자료를 준비하고, 포럼 폐회 식 전 참석기관 대상 동 자료를 배포함

- 캄보디아 개발협력위원회 의장이 폐회식에 서 포럼 중 진행된 논의 사항을 요약 발표하 며, $\mathrm{LDF}$ 는 원조공여기관을 대표하여 포럼 에 대한 전반적인 관찰 및 평가내용을 발표 하게 됨.

[자료: 주캄보디아대사관] 